\title{
Biological significance and therapeutic implication of resveratrol- inhibited Wnt, Notch and STAT3 signaling in cervical cancer cells
}

\author{
Peng Zhang ${ }^{1}$, Hong $\mathrm{Li}^{1}$, Bin Yang${ }^{2}$, Fan Yang ${ }^{2}$, Lin-Lin Zhang ${ }^{1}$, Qing-You Kong ${ }^{1}$, \\ Xiao-Yan Chen ${ }^{1}$, Mo-Li Wu ${ }^{1}$, Jia Liu ${ }^{1}$ \\ ${ }^{1}$ Liaoning Laboratory of Cancer Genetics and Epigenetics and Department of Cell Biology, College of Basic Medical Sciences, \\ Dalian Medical University, Dalian, China \\ 2 Department of Gynaecological Surgery, Sheng-Jing Hospital, China Medical University, Shenyang, China \\ Correspondence to: Jia Liu, email: jialiudl@aliyun.com
}

Keywords: Cervical cancers; Resveratrol; Molecular target; Signal transduction pathways; STAT3 signaling

Received: March 31, $2014 \quad$ Accepted: June 25, $2014 \quad$ Published: June 25, 2014

This is an open-access article distributed under the terms of the Creative Commons Attribution License, which permits unrestricted use, distribution, and reproduction in any medium, provided the original author and source are credited.

\section{ABSTRACT:}

Cervical cancers/CCs are one of the commonest malignancies and the second leading cause of cancer-related death in women. Resveratrol inhibits CC cell growth but its molecular target(s) remains unclear. Since the signaling pathways mediated by STAT3, Notch 1 and Wnt2 play beneficial roles in CC formation and progression, the effects of resveratrol on them in cervical adenocarcinoma (HeLa) and squamous cell carcinoma ( $\mathrm{SiHa}$ ) cells were analyzed. The biological significances of the above signaling for HeLa and SiHa cells were evaluated by treating the cells with STAT3, Wnt or Notch selective inhibitors. The frequencies of STAT3, Notch and Wnt activations in 68 cases of CC specimens and 38 non-cancerous cervical epithelia were examined by tissue microarray-based immunohistochemical staining. The results revealed that HeLa and SiHa cells treated by $100 \mu \mathrm{M}$ resveratrol showed extensive apoptosis, accompanied with suppression of STAT3, Notch and Wnt activations. Growth inhibition and apoptosis were found in HeLa and SiHa populations treated by AG490, a STAT3/ JAK3 inhibitor but not the ones treated by Notch inhibitor L-685,458 or by Wnt inhibitor XAV-939. Immunohistochemical staining performed on the tissue microarrays showed that the frequencies of Notch1, Notch2, Hes1, Wnt2, Wnt5a and p-STAT3 detection as well as $\beta$-catenin nuclear translocation in CC samples were significantly higher than that of noncancerous group $(p<0.01)$, while the expression rate of PIAS3 was remarkably low in cancer samples $(p<0.01)$. Our results thus demonstrate that STAT3, Wnt and Notch signaling are frequently co-activated in human CC cells and specimens and resveratrol can concurrently inhibit those signaling activations and meanwhile lead cervical squamous cell carcinoma and adenocarcinoma cells to growth arrest and apoptosis. STAT3 signaling is more critical for CC cells and is the major target of resveratrol because selective inhibition of STAT3 rather than Wnt or Notch activation commits SiHa and HeLa cells to apoptosis.

\section{INTRODUCTION}

Cervical cancers $(\mathrm{CC})$ are one of the leading causes of cancer-related death among women in developing countries $[1,2]$, which are classified into squamous cell carcinomas and adenocarcinomas according to their cellular origins [3]. Surgery is still the first choice of $\mathrm{CC}$ treatments, but frequent relapse and metastasis lead to poor prognosis of $\mathrm{CC}$ patients, especially those at advanced stage [4]. Chemotherapy has been widely used to prevent recurrence in postoperative management of CCs [5]. However, frequent drug resistance and severe toxicities damage patients' life quality [6]. It is therefore of clinical values to explore more reliable and less toxic therapeutic approach in the adjuvant treatment of cervical cancers.

Resveratrol (3, 5, 4'-trihydroxy-trans-stilbene), a phytoalexin, can be found in some edible food materials 
such as grape skins, pea-nuts and red wine [7, 8]. A body of evidence shows that this compound has multiple biological activities including induction of differentiation and apoptosis of cancer cells [9, 10]. For example, human medulloblastoma cells are sensitive to resveratrol in terms of growth arrest, neuron-oriented differentiation and distinct apoptosis [11]. And the growth of transplanted human transitional cell carcinomas in nude mouse urinary bladders can be efficiently suppressed by regular resveratrol installation [12]. More importantly, resveratrol has little harmful effect on glial cells and neurons in central nervous system and the tumor surrounding uroepithelium [13, 14], suggesting its potential values in the clinical treatments of those cancers. In the case of cervical cancers, resveratrol exerts radiosensitizing and anti-proliferative effects on them [15], but its underlying molecular mechanism remains to be investigated.

Resveratrol has multifaceted molecular effects on the treated cells. For instance, it can inhibit growth and induce apoptosis of human medulloblastoma and glioblastoma cells through suppressing the activations of several signaling pathways [16-18]. The current study thus aims to check 1) the statuses of STAT3-, Notchand Wnt-mediated signaling in a squamous carcinoma cell line, SiHa, and an adenocarcinoma cell line, HeLa, of the cervix, 2) the influence of resveratrol in the biological activities of the three signaling pathways and 3 ) the biological consequence(s) of selective inhibition of individual signaling to the two cell lines.

\section{RESULTS}

\section{Growth arrest and apoptosis of resveratrol- treated HeLa and SiHa cells}

$\mathrm{H} / \mathrm{E}$ morphologic staining demonstrated that HeLa and SiHa cells showed distinct apoptotic phenotypes after $100 \mu \mathrm{M}$ resveratrol treatment for 48 hours (Figure 1B).
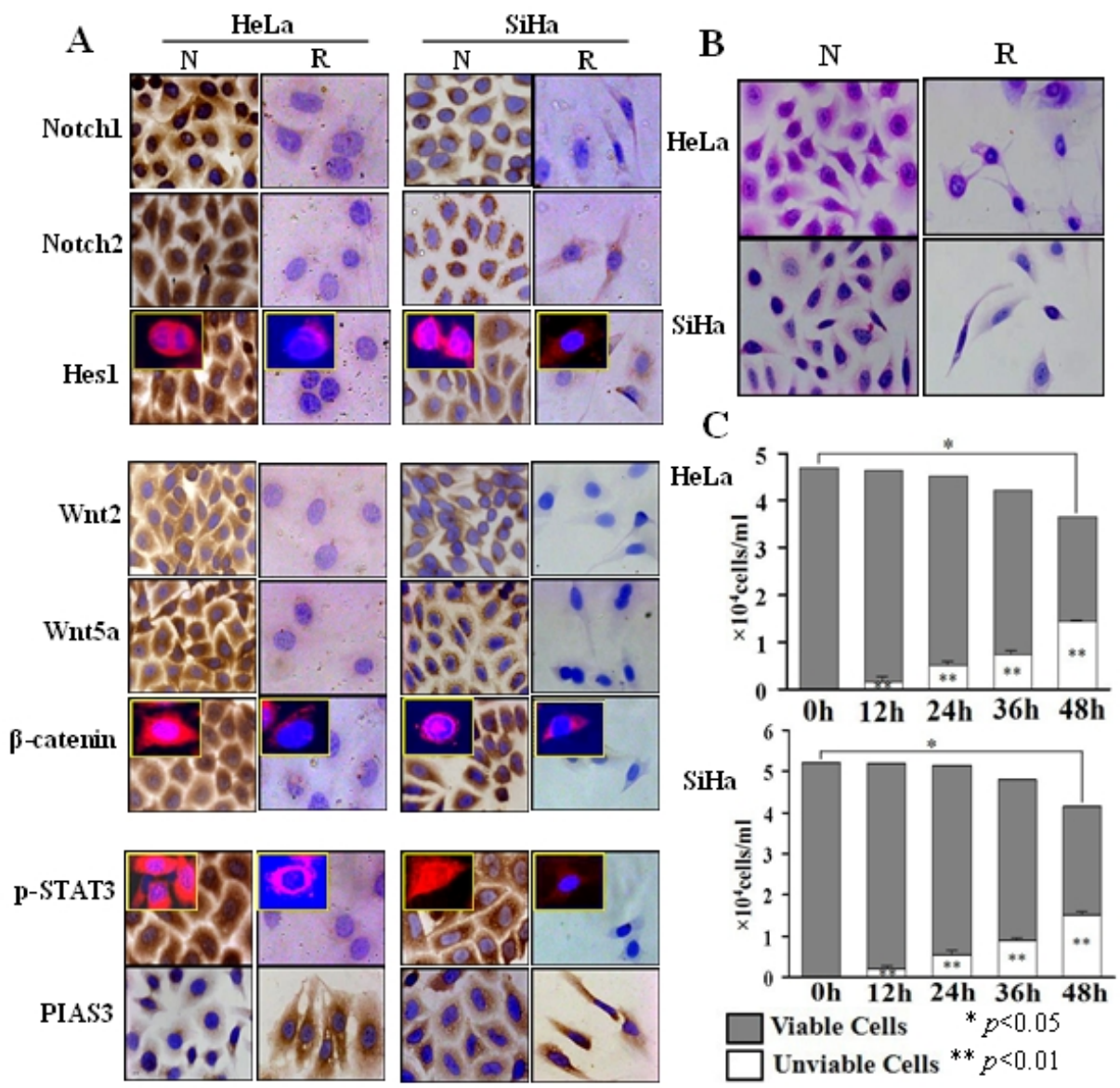

Figure 1: Inhibitory effects of resveratrol on cervical squamous cell carcinoma SiHa and adenocarcinoma HeLa cells. A: Immunocytochemical illustration of intracellular distribution of Notch1, Notch2, Hes1, Wnt2, Wnt5a, $\beta$-catenin, p-STAT3 and PIAS3 in HeLa and SiHa cells without (N) and with (R) $100 \mu \mathrm{M}$ resveratrol treatment for $48 \mathrm{~h}$. Immunofluorescent staining results were showed on the up-left corners. B: HE staining in HeLa and SiHa cells without $(\mathrm{N})$ and with $(\mathrm{R}) 100 \mu \mathrm{M}$ resveratrol treatment for 48h. C: Trypan blue discrimination of stained (unviable) and unstained (viable) cells. HeLa and SiHa cells were treated with $100 \mu \mathrm{M}$ resveratrol for $0 \mathrm{~h}, 12 \mathrm{~h}$, $24 \mathrm{~h}, 36 \mathrm{~h}$ and $48 \mathrm{~h}$ respectively. 
Trypan blue cell discrimination assay revealed increased cell death fractions and significant cell number reduction $(p<0.01$; Figure 1C) in the two resveratrol-treated populations. Flow cytometry further demonstrated that the percentages of $\mathrm{S}$ phase and apoptotic HeLa cells were $34.14 \%$ and $0 \%$ under normal culture condition, which increased to $64.62 \%$ and $38.62 \%$ in resveratrol-treated population (Figure 3B: N and R; $<<0.01$ ). AnnexinV-FITC and PI double dye labelling showed that the apoptotic cells (on the low-right quadrant, FITC+/PI) were $2 \%$ in normally cultured HeLa cells and reached to $39.1 \%$ after 48 hour $100 \mu \mathrm{M}$ resveratrol treatment. The similar phenomena were also found in resveratrol-treated $\mathrm{SiHa}$ cells (Figure 3C).

\section{Resveratrol inhibited Notch, Wnt and STAT3 activation}

Immunocytochemical/ICC staining (Figure 1A) showed that Notch1, Notch2, Wnt2 and Wnt5a were expressed in HeLa and SiHa cells and were downregulated when the cells were exposed to $100 \mu \mathrm{M}$ resveratrol for 48 hours. Predominant nuclear labelling of Hes $1, \beta$-catenin

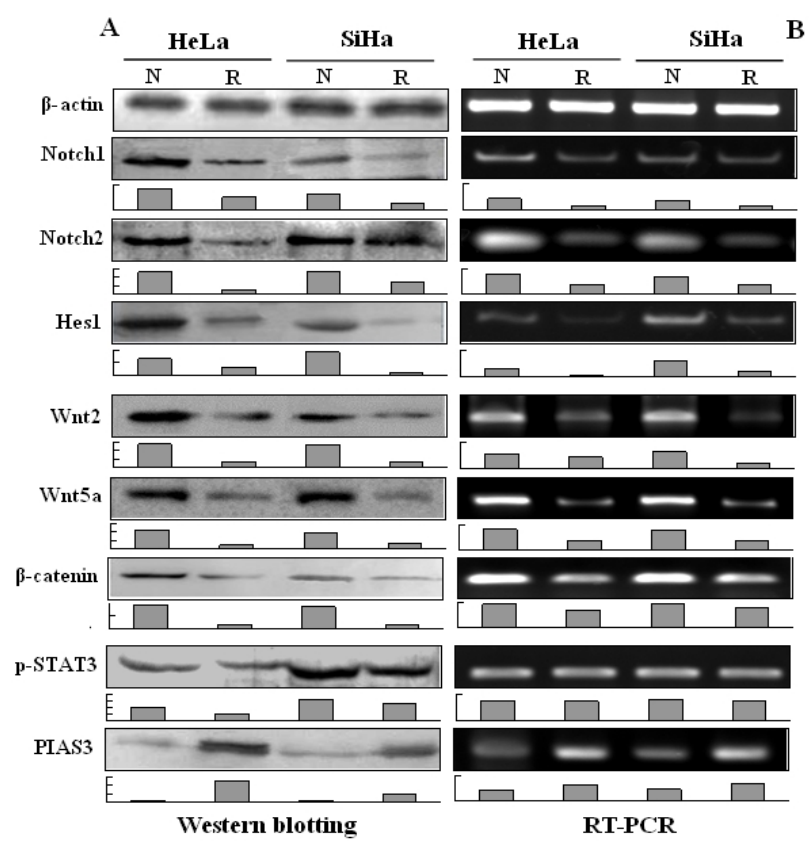

Figure 2: Statuses of STAT3, Notch and Wnt signaling in SiHa and HeLa cells and the influences of resveratrol in them. A: Evaluation of Notch1, Notch2, Hes1, Wnt2, Wnt5a, $\beta$-catenin, p-STAT3 (STAT3) and PIAS3 in HeLa and SiHa cells without $(\mathrm{N})$ and with $(\mathrm{R}) 100 \mu \mathrm{M}$ resveratrol treatment for $48 \mathrm{~h}$ by Western blotting and B: RT-PCR, $\beta$-actin was used as a quantitative control. Gray analyses of the Western blotting and RT-PCR results were under each picture, the ordinate was the ratio of each index and $\beta$-actin grey value. and p-STAT3 were found in normally cultured HeLa and $\mathrm{SiHa}$ cells, which became weakened by resveratrol. The protein inhibitor of activated STAT3 (PIAS3) was expressed in low level in HeLa and $\mathrm{SiHa}$ cells under normal culture condition and was up-regulated after resveratrol treatment (Figure 1A). Paralleled RT-PCR and Western blot analyses showed that Notch1, Notch2, Hes1, Wnt2, Wnt5a and $\beta$-catenin were obviously downregulated and PIAS3 was up-regulated in resveratroltreated HeLa and SiHa cells (Figure 2A and 2B; $\mathrm{p}<0.05$ ). Although the levels of STAT3 expression remained largely unchanged between normally cultured and resveratroltreated HeLa or SiHa cells (Figure 2B), p-STAT3 levels were reduced in resveratrol-treated HeLa and SiHa cells in the extents of $51.8 \%$ and $19.7 \%$, respectively (Figure 2A).

\section{Variable sensitivities to Notch, Wnt and STAT3 inhibitors}

To evaluate potential biological significance of Notch, Wnt and STAT3 activations in the two CC cells, the selective inhibitors of the three signalling pathways were used to treat HeLa and SiHa cells, respectively. The results revealed that $8 \mu \mathrm{M}$ L-685,458 blocked Notch activation in the two cell lines in terms of reduced cytoplasmic distribution and almost diminished nuclear labelling of Hes1 proteins (Figure 3A). However, this treatment neither brought about growth arrest and cell death nor the cell cycle alteration. (Figure $3 \mathrm{~B}$ and $3 \mathrm{C}: \mathrm{N}$ and $\mathrm{L}$ ). XAV-939-treated HeLa and SiHa cells showed reduction of cytoplasmic distribution and nuclear translocation of $\beta$-catenin without distinct morphologic change and growth inhibition (Figure 3A). STAT3 phosphorylation was inhibited in HeLa and SiHa cells upon $80 \mu \mathrm{M}$ AG490 treatment for 48 hours (Figure 3A). $61.95 \%$ of AG490treated HeLa cells were arrested in S-phase and 40.22\% underwent apoptosis. In the case of AG490-treated $\mathrm{SiHa}$ cells, the S-phase and apoptotic cells were $43.54 \%$ and $27.25 \%$ respectively in comparison with $17.60 \%$ and $0 \%$ of their normally cultured counterparts (Figure $3 \mathrm{~B}$; $\mathrm{p}<0.05)$.

\section{Frequent co-activations of Notch, Wnt and STAT3 signaling in cervical cancer specimens}

The results of tissue microarray-based immunohistochemical staining were summarized in Table 1 and shown in Figure 4. It was found that p-STAT3 could be detected in 6 of $38(15.8 \%)$ non-cancerous cervical epithelia, in $84.0 \%(21 / 25 ; \mathrm{p}<0.01)$ adenocarcinomas and in 36 of $43(83.7 \%$; $<<0.01)$ squamous cell carcinomas. Similarly, the frequencies of Notch 1 , Notch2, Wnt2 and Wnt5a detection as well as nuclear translocation of Hes 1 and $\beta$-catenin in CCs were significantly higher than the noncancerous group $(p<0.01)$. The expression rates of 
intrinsic STAT3 inhibitor PIAS3 were 52.6\% (20/38) among noncancerous epithelial tissues but reduced to $16.0 \%(4 / 25 ; \mathrm{p}<0.01)$ and $11.6 \%(5 / 43 ; \mathrm{p}<0.01)$ in cervical adenocarcinoma and squamous carcinoma samples, respectively.

\section{DISCUSSION}

Cervical carcinoma is the second commonest malignant tumor of women in the world [19]. The outcome of localized cervical cancers treated by surgery and/or chemo-radiation therapies is promising, while the
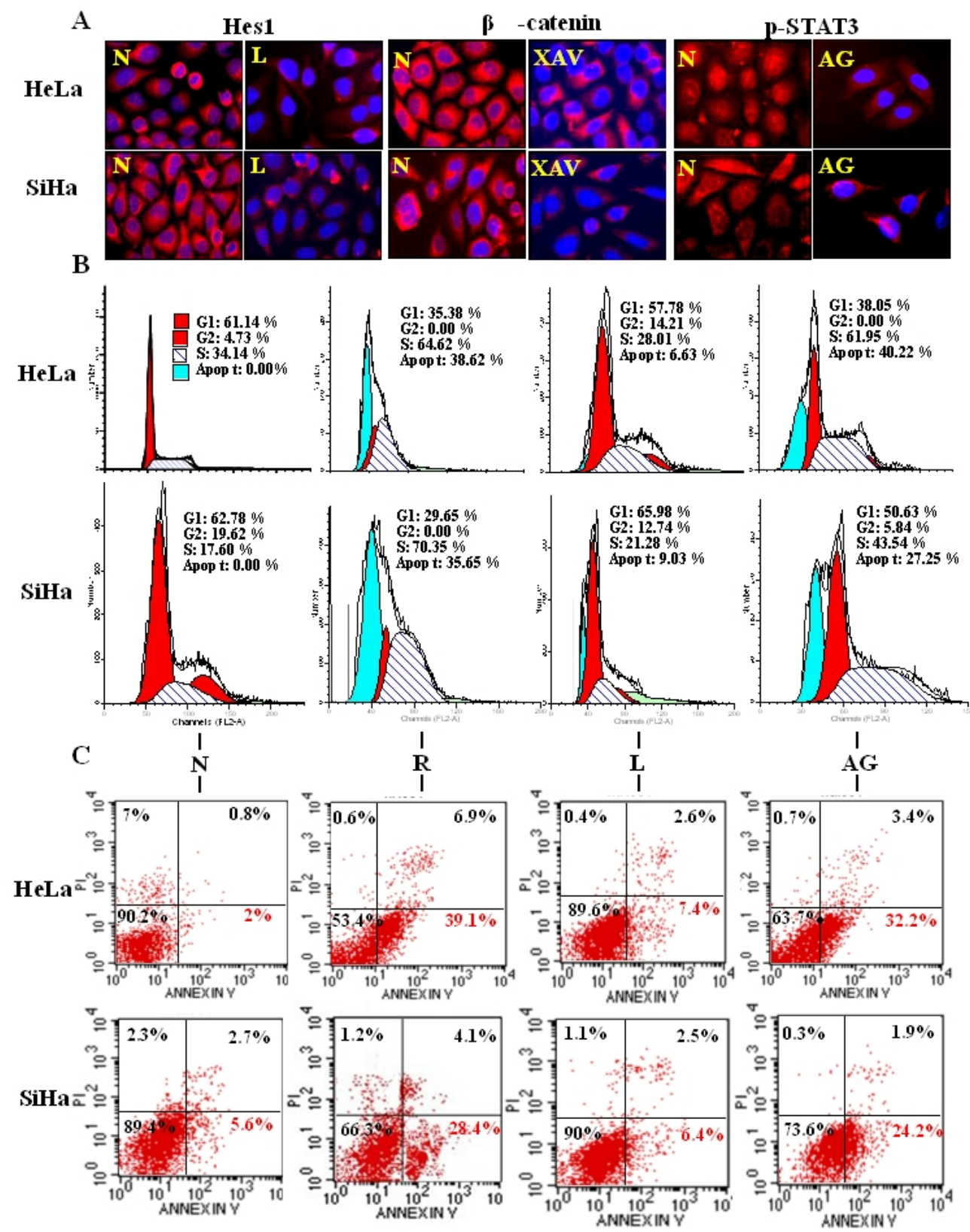

Figure 3: Evaluation of the effects of STAT3, Notch and Wnt selective inhibitors on HeLa and SiHa cells. A:

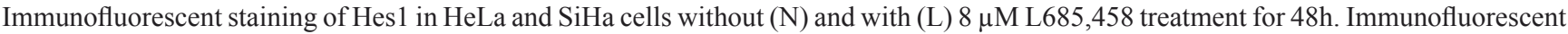
staining of $\beta$-catenin in HeLa and SiHa cells without (N) and with (XAV) $10 \mu \mathrm{M}$ XAV-939 treatment for 48h. Immunofluorescent staining of p-STAT3 in HeLa and SiHa cells without (N) and with (AG) $80 \mu \mathrm{M}$ AG490 treatment for 48h. B: Flow cytometry analyses of cell cycle

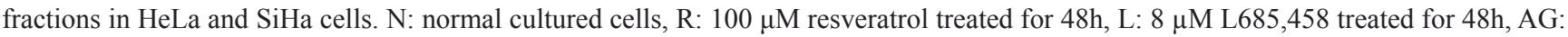
$80 \mu \mathrm{M}$ AG490 treated for 48h. C: Flow cytometry analyses of cell apoptosis fractions in HeLa and SiHa cells. PI/AnnexinV-FITC double staining. The percentage of each group of data was in the quadrant, UR: necrotic cells (FITC-/PI-), LL: viable cells (FITC+/PI+), LR: apoptotic cells (FITC+/PI-). 
prognosis of Stage III and IV cervical cancers is poor with 5-year survival rates of $43.2 \%$ and $13 \%$ respectively, because of the extensive local invasion and frequent distal metastasis [20-22]. Cisplatin and paclitaxel are currently used as the first-line chemotherapeutic drug for cervical cancers but its efficacy is not promising because of the drug resistance and the serious adverse reactions [23, 24]. It is therefore in urgent need to explore a safer and more effective agent against cervical cancers $[25,26]$.

Resveratrol is increasingly recognized as a potential cancer preventive and therapeutic agent [27]. A body of evidence indicates that resveratrol has inhibitory effects on many types of malignancies including the squamous cell carcinomas and adenocarcinomas of uterus cervical cancers $[28,29]$. Nevertheless, the molecular mechanism underlying the effects of resveratrol on cervical cancers remains unclear. On the other hand, multiple cancer associated signaling pathways are activated in human cervical cancers and considered as potential therapeutic target(s) in the treatment of those cancers [30-33]. Notch signaling in $\mathrm{CD}^{+} 6^{+}$cells drives the progression of human cervical cancers [34]. The in vivo growth, invasion and angiogenesis of cervical cancer can be inhibited by Wnt inhibitory factor 1 [35]. And STAT3 signaling is constitutively activated in cervical cancer and may play potential role in progression of HPV16-mediated cervical carcinogenesis [36]. A body of evidence demonstrates that the multifaceted biological activities of resveratrol are reflected by its inhibitory effects on the activations of cancer-associated signaling pathways [37-39]. For these reasons, the statuses of Wnt, Notch and STAT3 signaling in $\mathrm{HeLa}$ and $\mathrm{SiHa}$ cells without and with resveratrol treatment were investigated in currently.

It was found that resveratrol in the dose of $100 \mu \mathrm{M}$ efficiently inhibited the growth and suppressed Wnt2, Wnt5a, Notch1 and Notch2 expression of the two cell lines. Although transcriptional levels of STAT3 remained almost unchanged between the normally cultured and resveratrol-treated HeLa and SiHa cells, phosphorylation of STAT3 was obviously inhibited by resveratrol, accompanied with distinct PIAS3 up-regulation, indicating that these two events may be the main reasons of STAT3
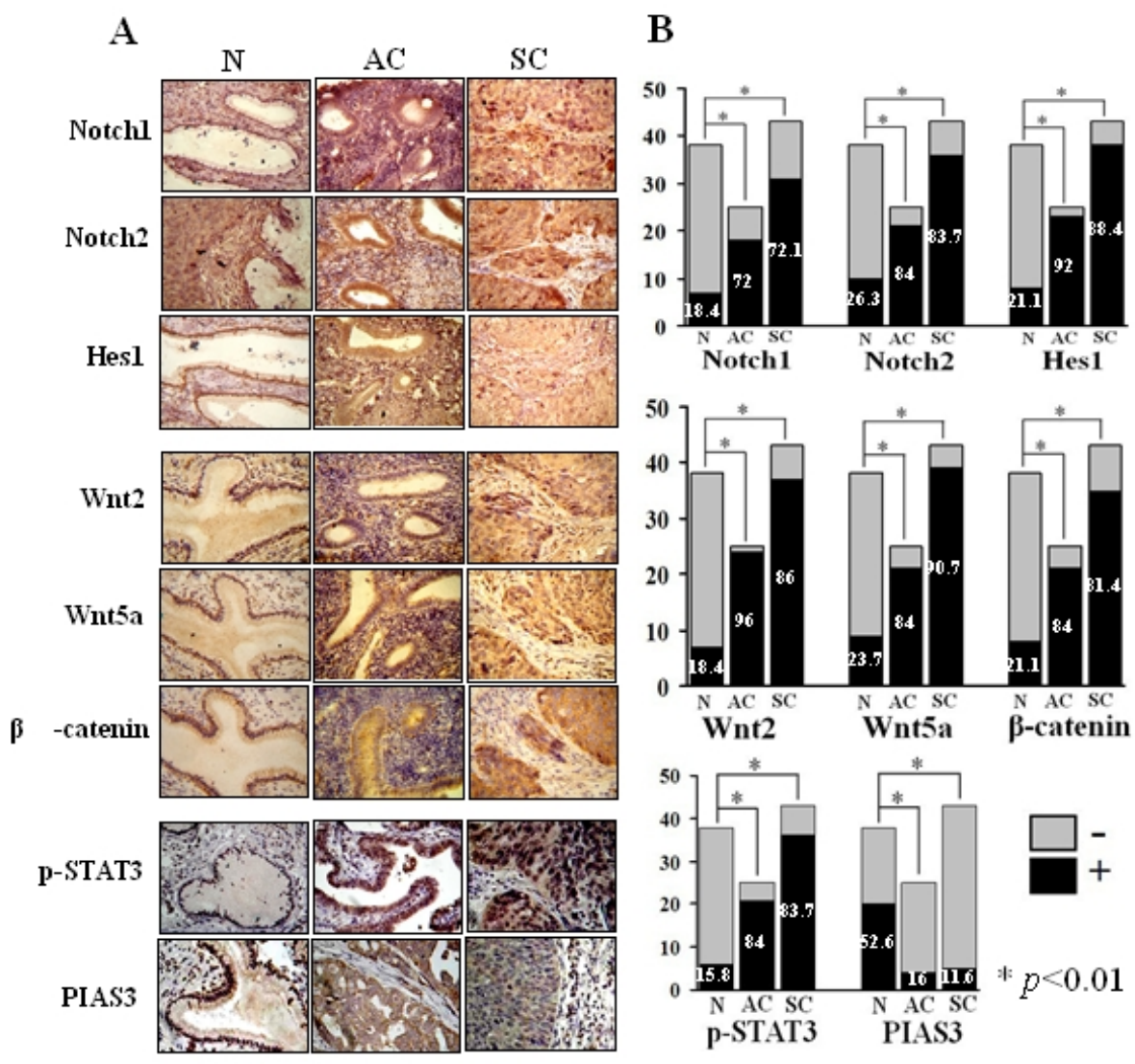

Figure 4: Frequencies of Notch1, Notch2, Wnt2 and Wnt5a detection and nuclear translocation of Hes1, $\beta$-catenin, p-STAT3 and PIAS3 in human cervical cancer specimens. A: Tissue microarray-based immunohistochemical staining for Notch1, Notch2, Hes1, Wnt2, Wnt5a, $\beta$-catenin, p-STAT3 and PIAS3 in normal cervical tissues removed from the uterine fibroid patients at post-reproduction ages $(\mathrm{N})$, cervical adenocarcinomas (AC) and cervical squamous cell carcinomas (SC) (original magnifications $\times 400$ ). B: Histogram of Table $1,{ }^{*} \mathrm{p}<0.01$. 
Table 1: Immunohistochemical profiling of Notch1, Notch2, Hes1, Wnt2, Wnt5a, $\beta$-catenin, p-STAT3 and PIAS3 expression in human cervical tissues.(N: normal cervical tissues removed from the uterine fibroidpatients at post-reproduction ages, AC: cervical adenocarcinomas, SC: cervical squamous cell carcinomas. $\left.{ }^{*} \mathrm{p}<0.01\right)$

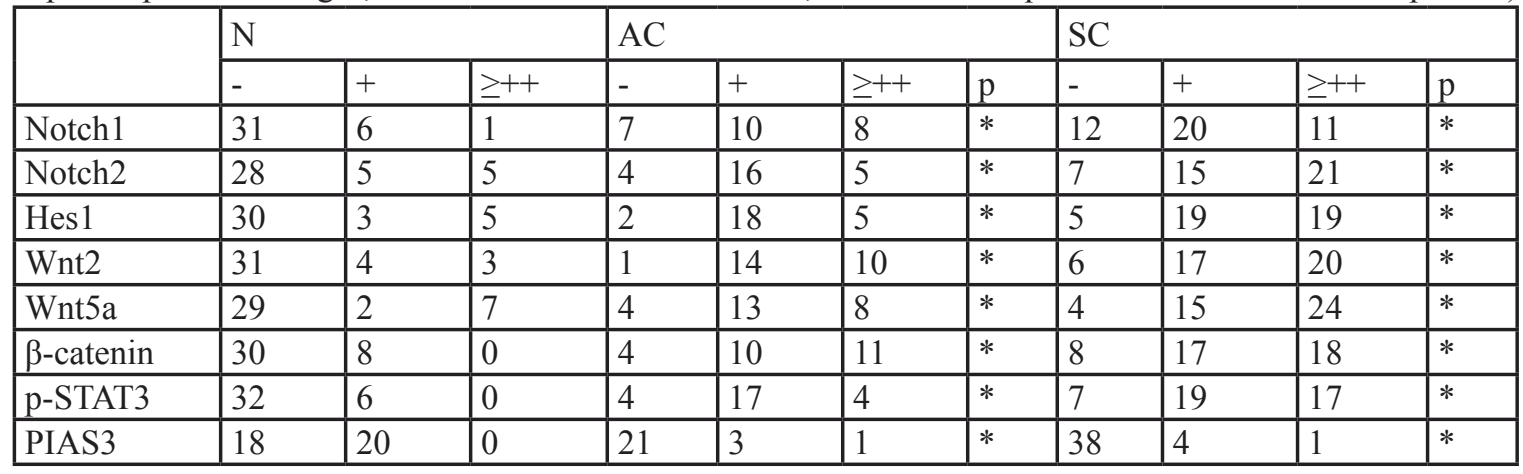

Table 2: The primer sequences of polymerase chain reactions

\begin{tabular}{|c|c|c|c|}
\hline Parameters & Primer Sequence $\left(5^{\prime} \rightarrow 3^{\prime}\right)$ & Product size & Reference \\
\hline \multirow{2}{*}{$\beta$-actin } & f: 5' - GCA TGG AGT CCT GTG GCA T - 3' & \multirow{2}{*}{326} & \multirow{2}{*}{49} \\
\hline & r: 5' - CAT GAA GCA TTT GCG GTG G - 3' & & \\
\hline \multirow{2}{*}{ Notch1 } & f: 5' - TGT GAC AGC CAG TGC AAC TC - 3' & \multirow{2}{*}{577} & \multirow{2}{*}{50} \\
\hline & r: 5' - TGG CAC TCT GGA AGC ACT GC - 3' & & \\
\hline \multirow{2}{*}{ Notch 2} & f: 5' - AAT GTC ATG GCC GCT TCA GAG - 3' & \multirow{2}{*}{533} & \multirow{2}{*}{51} \\
\hline & r: 5' - TCG TGC AAG AGC CAG TTA CCC - 3' & & \\
\hline \multirow{2}{*}{ Hes 1} & f: 5' - CCA GTT TGC TTT CCT CAT TCC - 3' & \multirow{2}{*}{240} & \multirow{2}{*}{52} \\
\hline & r: 5' - TCT TCT CTC CCA GTA TTC AAG TTC C - 3' & & \\
\hline \multirow{2}{*}{ Wnt2 } & f: 5' - GCC ACA CGC TGC ACC TAA AGC - 3' & \multirow{2}{*}{379} & \multirow{2}{*}{53} \\
\hline & r: 5' - CAA TTA CCC TAA GGG TGG TAG C - 3' & & \\
\hline \multirow{2}{*}{ Wnt5a } & f: 5' - CTA ACT TAG CTG TGT GGG ACA TG - 3' & \multirow{2}{*}{254} & \multirow{2}{*}{54} \\
\hline & r: 5' - AAA TGC AGA AAG CAA GCT AGC AG - 3', & & \\
\hline \multirow{2}{*}{$\beta$-catenin } & f: 5' - ACA AAC TGT TTT GAA AAT GG - 3' & \multirow{2}{*}{298} & \multirow{2}{*}{55} \\
\hline & r: 5' - CGA GTC ATT GCA TAC TGT CC -3' & & \\
\hline \multirow{2}{*}{ STAT3 } & f: 5'- GGG TGG AGA AGG ACA TCA GCG GTA A - 3' & \multirow{2}{*}{198} & \multirow{2}{*}{56} \\
\hline & r: 5' - GCC GAC AAT ACT TTC CGA ATG C - 3' & & \\
\hline \multirow{2}{*}{ PIAS3 } & f: 5' - ACG CTG TTG GCC CCT GGC AC - 3' & \multirow{2}{*}{322} & \multirow{2}{*}{57} \\
\hline & r: 5' - GGG GCT CGG CCC CAT TCT TGG - 3' & & \\
\hline
\end{tabular}

inactivation. These findings further confirm the multiple targeting features of resveratrol and, meanwhile, suggest potential therapeutic effectiveness of resveratrol on both squamous cell carcinomas and adenocarcinomas of human cervical uterus. Given the reduced activities of Wnt, Notch and STAT3 signaling in resveratrol-treated cervical cancer cells, it would be worthwhile to evaluate the significance of Wnt, Notch or STAT3 signaling for CC cells and the biological consequence of their inhibition.

One of the efficient approaches to block the pathway of signal transduction is to employ an appropriate selective inhibitor [40, 41]. Therefore, XAV-939, L-685,458 and AG490 were used to respectively inhibit Wnt-, Notchand STAT3-mediated signaling in $\mathrm{HeLa}$ and $\mathrm{SiHa}$ cells. Although nuclear translocation of $\beta$-catenin was remarkably reduced by XAV-939, HeLa and SiHa cells with the treatment showed little morphological change and growth arrest, suggesting that Wnt signaling might not be crucial for the two types of cervical cancer cell lines. Hes 1 is the downstream gene of Notch signaling [42]. In 
L-685,458-treated cells, Hes1 nuclear translocation was largely blocked and about $6.63 \%$ of HeLa and $9.03 \%$ of $\mathrm{SiHa}$ cells were subjected to apoptosis, indicating that Notch signaling may play certain favourable roles in the two cell lines. When AG490 was used, STAT3 phosphorylation and nuclear translocation in HeLa and SiHa cells were successfully inhibited. More importantly, S-phase arrest was found in AG490-treated SiHa (43.54\%) and especially HeLa cells (61.95\%), accompanied with remarkable apoptosis $(27.25 \%$ and $40.22 \%)$. These phenomena are very similar with that of resveratrol-treated cells in which the fractions of S-phase and apoptosis increase to $70.35 \%$ and $35.65 \%$ in $\mathrm{SiHa}$ and to 64.62 $\%$ and $38.62 \%$ in HeLa cells. It is therefore strongly suggested that among the three resveratrol inhibited signaling pathways so far checked, inactivation of STAT3 signaling is the lethal molecular event in Hela and $\mathrm{SiHa}$ cells. Alternatively, the activated STAT3 signaling seems more crucial than the other two in the proliferation and survival of human cervical cancers although Notch signaling may also play certain roles in those processes. In this context, STAT3 targeting strategy would be applicable in the management of this sort of woman malignancies and the less toxic resveratrol with multifaceted actions is an optimal choice.

The involvements of Wnt, Notch and STAT3 signaling in cervical carcinogenesis have been described [43-45]. However, the paralleled analyses of their statuses in a panel of $\mathrm{CC}$ and noncancerous specimens are still limited. Since activated Notch and, especially STAT3 signaling as the molecular targets of resveratrol are critical in the growth and survival of $\mathrm{SiHa}$ and HeLa cells, the frequencies of Wnt, Notch and STAT3 activation in the two types of CCs were elucidated to correlate the in vitro findings with the in vivo statuses. Our immunohistochemical results revealed that in comparison with the data obtained from the noncancerous cervical mucosa, these three signaling pathways are frequently activated $(\mathrm{p}<0.01)$ and the expression of PIAS3 was uncommon $(11.6 \%, 5 / 43, \mathrm{p}<0.01)$ in cervical cancers irrespective to their cell origins. In accordance to the findings from $\mathrm{SiHa}$ and HeLa cells, Wnt, Notch and STAT3 co-activations could be detected in $79.1 \%$ (34/43) of squmous cell carcinomas and 80\% (20/25) of adenocarcinomas, suggesting their potential crosstalk in regulating cancer-related gene expression during the stepwise cervical carcinogenisis $[46,47]$. Since resveratrol can concurrently inactivates Wnt, Notch and STAT3 signaling in $\mathrm{SiHa}$ and HeLa cells, this multi-targeting compound would be of practical values in the prevention and treatment of cervical squamous cell carcinomas and adenocarcinomas.

\section{MATERIALS AND METHODS}

\section{Cell culture and treatments}

Human cervical adenocarcinoma cell line HeLa (Cat No: TCHu187) and human cervical squamous carcinoma cell line SiHa (Cat No: TCHu113) were provided by Cell Bank of Academia Sinica, Shanghai. HeLa cells were cultured in Roswell Park Memorial Institute 1640 Medium (RPMI1640, Gibco Life Science, Grand Island, NY, USA) and SiHa cells were cultured in MEM essential medium containing 10\% fetal bovine serum (Gibco Life Science, Grand Island, NY, USA) under $37^{\circ} \mathrm{C}$ and $5 \%$ $\mathrm{CO}_{2}$ condition. They $\left(5 \times 10^{4} / \mathrm{ml}\right)$ were plated to $\varnothing 100 \mathrm{~mm}$ dishes (NUNC, Denmark) and incubated for $24 \mathrm{~h}$ before further experiments. Resveratrol (Sigma Chemical, Inc, St. Louis, MO) was dissolved in dimethylsulfoxide (DMSO, Sigma) to a stock concentration of $100 \mathrm{mM}$ and diluted with culture medium to an optimal working concentration of $100 \mu \mathrm{M}$ just before use [48]. For H/E morphologic and immunocytochemical/ICC staining, the coverslips were put into the dishes before initial cell seeding and collected regularly during the experiments.

\section{Morphologic examination and cell proliferation assay}

Total cell numbers and cell viability of HeLa and $\mathrm{SiHa}$ cells without and with $100 \mu \mathrm{M}$ resveratrol treatment were determined in 12-h intervals by staining the single cell suspensions with $2 \%$ trypan blue and counting the stained and unstained cells with the haemocytometers. The effects of resveratrol and the selective inhibitors of Wnt (8 $\mu \mathrm{M}$ L685, 458), Notch (10 $\mu \mathrm{M}$ XAV-939) and STAT3 $(80 \mu \mathrm{M}$ AG490) pathway on cell cycle and apoptosis of HeLa and $\mathrm{SiHa}$ cells were evaluated by flow cytometry. For staining with DNA dye, the cells were suspended in $0.5 \mathrm{ml}$ to $1 \mathrm{ml}$ of propidium iodide solution containing RNase and incubated at $37^{\circ} \mathrm{C}$ for 30 minutes. Cell cycle and cell apoptosis profiles were obtained with a FACSvantage flow cytometer (Becton Dickinson, San Jose, CA). The data obtained were analyzed with ModFit software (Verity Software House, Inc, Topsham, ME).

\section{Immunocytochemical and immunofluorescent staining}

Immunocytochemical staining (ICC) was performed on the coverslips obtained from each of the experimental groups. The antibodies used were a mouse anti-human Notch1 monoclonal antibody (1:100, NeoMarkers, Inc, Fremont, California), a rabbit anti-human Notch2 polyclonal antibody (1:100, Santa Cruz, CA, USA), a 
rabbit anti-human Hes1 polyclonal antibody (1:1000; a generous gift of Tetsuo Sudo, PhD, Toray Industries, Tokyo, Japan), a goat anti-human Wnt2 (1:100; Santa Cruz, CA, USA), a rabbit anti-human Wnt5a polyclonal antibody(1:100; Santa Cruz, CA, USA), a mouse antihuman $\beta$-catenin $(1: 100$; Santa Cruz, CA, USA), a rabbit anti-human p-STAT3(1:100; Santa Cruz, CA, USA) and a rabbit anti-human PIAS3 polyclonal antibody (1:100; Santa Cruz, CA, USA). All of the antibodies were used according to the manufacturer's instruction. ICC staining was conducted by the method described elsewhere [16]. For immunofluorescent (IF) staining, the coverslips were rinsed with PBS ( $\mathrm{pH} 7.4$ ), fixed for 20 minutes in $80 \%$ cold acetone and stored at $-20^{\circ} \mathrm{C}$ until use. After being blocked with $10 \%$ goat serum in PBS for 20 minutes, the coverslips were incubated overnight with primary antibodies against Hes $1, \beta$-catenin and p-STAT3 in humid chamber at $4^{\circ} \mathrm{C}$, followed by coincubation with fluorescence-labeled goat anti-rabbit and rabbit anti-mouse IgG (1:100; Santa Cruz, CA, USA) in a $37^{\circ} \mathrm{C}$ humid chamber for 60 minutes in darkness. DAPI (4',6-diamidino-2-phenylindole,2-(4-amidinophenyl)-

1H-indole-6-carboxamidine) was used to stain nuclei with blue fluorescent. After being sealed with $90 \%$ glycerol, the coverslips were observed and photographed (DP70 Digital Camera; Olympus, Tokyo, Japan) under a fluorescence microscope (BX51; Olympus).

\section{RNA isolation and reverse transcription- polymerase chain reaction}

Total cellular RNA was isolated from each of experimental groups using Trizol solution (Life Technologies, Grand Island, NY). Reverse transcription (RT) was performed on RNA samples, followed by polymerase chain reaction (PCR) amplification. For $\mathrm{RT}, 0.5 \mu \mathrm{g}$ of the RNA sample was added to $20 \mu \mathrm{l}$ of RT reaction mixture (Takara, Inc, Ltd, Dalian, China) containing $4 \mu \mathrm{l}$ of $\mathrm{MgCl}_{2}, 2 \mu \mathrm{l}$ of $10 \times \mathrm{RNA}$ PCR buffer, $9.5 \mu \mathrm{l}$ of RNase-free distilled $\mathrm{H}_{2} \mathrm{O}, 2 \mu \mathrm{l}$ of deoxyribonucleotide triphosphate mixture, $0.5 \mu \mathrm{l}$ of RNase inhibitor, $1 \mu \mathrm{l}$ of AMV reverse transcriptase, and $1 \mu \mathrm{l}$ of oligo dT-adaptor primer. The reaction was carried out by treating the samples at $55^{\circ} \mathrm{C}$ for 30 minutes, at $99^{\circ} \mathrm{C}$ for 5 minutes, and at $5^{\circ} \mathrm{C}$ for 5 minutes. Polymerase chain reaction was conducted using the primers specific for each of the target genes (Table 2). Briefly, $2.5 \mu$ l of RT products were mixed with $16 \mu \mathrm{l}$ of PCR-grade water, then with 6.5 $\mu \mathrm{l}$ of PCR working solution containing $1 \times \mathrm{PCR}$ buffer, $1 \mu \mathrm{l}$ of deoxyribonucleotide triphosphate, 2.5 units of Taq DNA polymerase, and $50 \mathrm{pM}$ upstream and downstream primers for human Notch1, Notch2, Hes1, Wnt2, Wnt5a, $\beta$-catenin, STAT3 and PIAS3 respectively. Polymerase chain reactions for individual genes were performed according to the conditions reported elsewhere [49-57].
The PCR products were resolved on $1 \%$ agarose gel containing ethidium bromide $(0.5 \mu \mathrm{g} / \mathrm{ml})$. The bands were visualized and photographed using UVP Biospectrum Imaging System (UVP, Inc, Upland, CA). The PCR products generated from the same RT solution by a pair of $\beta$-actin primers were cited as internal quantitative controls.

\section{Protein preparation and Western blotting}

Total cellular proteins were prepared from the cells under different culture conditions by the method described previously [16]. For Western blot analyses, the sample proteins $(50 \mu \mathrm{g} /$ well) were separated by electrophoresis in $10 \%$ sodium dodecylsulfate-polyacrylamide gel electrophoresis (SDS-PAGE), transferred to polyvinylidene difluoride membrane (Amersham, Buckinghamshire, UK). The membranes were blocked with 5\% skimmed milk in TBS-T (10 mM Tris-Cl, pH 8.0, $150 \mathrm{mM} \mathrm{NaCl}$, and $0.5 \%$ Tween 20 ) at $4^{\circ} \mathrm{C}$ overnight, rinsed three times (10 minutes each time) with TBS-T, followed by 3 hours of incubation at room temperature with the first antibodies in appropriate concentrations (Notch1: 1:800, Notch2: 1:800, Hes1: 1:2500, Wnt2: 1:500, Wnt5a: 1:500, $\beta$-catenin:1:400, p-STAT3: 1:800, PIAS3: 1:1000), followed by 1 hour incubation with HRP-conjugated anti-mouse or -rabbit IgG (ZymedLab, Inc). The bound antibody was detected using the enhanced chemiluminescence system (Roche GmbH, Mannheim, Germany). After removing the labelling signal by incubation with stripping buffer $(62.5 \mathrm{mM}$ Tris- $\mathrm{HCl}, \mathrm{pH}$ $6.7,100 \mathrm{mM}$ 2-mercaptoethanol, $2 \% \mathrm{SDS}$ ) at $55^{\circ} \mathrm{C}$ for 30 minutes, the membrane was reprobed with other antibodies one by one by the same experimental procedures until all of the parameters were examined.

\section{Inhibition of Wnt, Notch and STAT3 signaling with selective inhibitors}

L-685,458 (Calbiochem, San Diego, CA) is a potent and selective $\gamma$-secretase inhibitor, which inhibits Notch activation [58]. XAV-939 (Selleck, Houston, Texas, USA) selectively suppresses the transcription of $\mathrm{Wnt} / \beta$-catenin through inhibiting tankyrase1/2 [59]. AG490 (Sigma, Inc, St. Louis, MO), a JAK-specific inhibitor, can suppress STAT3 signaling by inhibiting Tyr705 phosphorylation of STAT3 protein [60]. To evaluate the importance of the three signalling pathways in the growth and survival of CC cells, $8 \mu \mathrm{M}$ L-685,458 [58], HeLa and SiHa cells were treated by $10 \mu \mathrm{M}$ XAV-939 [59] and $80 \mu \mathrm{M}$ AG490 [13], respectively. The treatments lasted for 72 hours and the cells were observed in 12 hour intervals. The cell bearing coverslips prepared were subjected to further analyses. The experiments were repeated for 3 times to establish confidential conclusion. 


\section{Tissue microarray-based immunohistochemical staining}

The archived paraffin blocks of 25 cases of adenocarcinomas, 43 squamous cell carcinomas cervical cancers and 38 normal cervical tissues removed from the uterine fibroid patients at post-reproduction ages. Tissue microarrays in the densities of $56 \mathrm{spots} / \mathrm{cm}^{2}$ were constructed by the method described elsewhere [33]. The microarrays prepared were sectioned to $5-\mu \mathrm{m}$ thickness for immunohistochemical profiling of Notch1, Notch2, Hes1, Wnt2, Wnt5a, $\beta$-catenin, p-STAT3 and PIAS3 expression and intracellular distribution, respectively. The antibodies used were the same as that used in immunocytochemistry. The tissue microarray sections lacking incubation with individual primary antibodies were used as background controls. The staining results were evaluated separately by two investigators, with the intensity of immunolabeling scored as negative (-), weakly positive $(+)$, moderately positive $(++)$ or strongly positive $(+++)$.

\section{Statistical analysis}

The results of cell counting were evaluated with the independent-samples t-test and ANOVA. Mann-Whitney tests were used to analyze the expression status in different histological groups. Statistical significance was defined as $\mathrm{p}<0.05$.

\section{REFERENCES}

1. Schiller JT and Davies P. Delivering on the promise: HPV vaccines and cervical cancer. Nat Rev Microbiol. 2004; 2(4):343-347.

2. Ojesina AI, Lichtenstein L, Freeman SS, Pedamallu CS, Imaz-Rosshandler I, Pugh TJ, Cherniack AD, Ambrogio L, Cibulskis K, Bertelsen B, Romero-Cordoba S, Treviño V, Vazquez-Santillan K, Guadarrama AS, Wright AA, Rosenberg MW, et al. Landscape of genomic alterations in cervical carcinomas. Nature. 2014; 506(7488):371-375.

3. Hirschowitz L, Nucci $M$ and Zaino RJ. Problematic issues in the staging of endometrial, cervical and vulval carcinomas. Histopathology. 2013; 62(1):176-202.

4. Touboul C, Uzan C, Mauguen A, Gouy S, Rey A, Pautier P, Lhommé C, Duvillard P, Haie-Meder C and Morice P. Prognostic factors and morbidities after completion surgery in patients undergoing initial chemoradiation therapy for locally advanced cervical cancer. Oncologist. 2010; 15(4):405-415.

5. Liu SY and Zheng PS. High aldehyde dehydrogenase activity identifies cancer stem cells in human cervical cancer. Oncotarget. 2013; 4(12):2462-2475.

6. Kumar S, Rana ML, Verma K, Singh N, Sharma AK, Maria AK, Dhaliwal GS, Khaira HK and Saini S. PrediQt-Cx: post treatment health related quality of life prediction model for cervical cancer patients. PLoS One. 2014; 9(2):e89851.

7. Baur JA, Pearson KJ, Price NL, Jamieson HA, Lerin C, Kalra A, Prabhu VV, Allard JS, Lopez-Lluch G, Lewis K, Pistell PJ, Poosala S, Becker KG, Boss O, Gwinn D, Wang $\mathrm{M}$, et al. Resveratrol improves health and survival of mice on a high-calorie diet. Nature. 2006; 444(7117):337-342.

8. Leone S, Basso E, Polticelli F and Cozzi R. Resveratrol acts as a topoisomerase II poison in human glioma cells. Int J Cancer. 2012; 131(3):e173-178.

9. Aires V, Limagne E, Cotte AK, Latruffe N, Ghiringhelli and Delmas D. Resveratrol metabolites inhibit human metastatic colon cancer cells progression and synergize with chemotherapeutic drugs to induce cell death. Mol Nutr Food Res. 2013; 57(7):1170-1181.

10. Tang Q, Li G, Wei X, Zhang J, Chiu JF, Hasenmayer D, Zhang D and Zhang H. Resveratrol-induced apoptosis is enhanced by inhibition of autophagy in esophageal squamous cell carcinoma. Cancer Lett. 2013; 336(2):325337.

11. Wang Q, Li H, Wang XW, Wu DC, Chen XY and Liu J. Resveratrol promotes differentiation and induces Fasindependent apoptosis of human medulloblastoma cells. Neurosci Lett. 2003; 351(2):83-86.

12. Wu ML, Li H, Yu LJ, Chen XY, Kong QY, Song X, Shu $\mathrm{XH}$ and Liu J. Short-term resveratrol exposure causes in vitro and in vivo growth inhibition and apoptosis of bladder cancer cells. PLoS One. 2014; 9(2):e89806.

13. Shu XH, Li H, Sun XX, Wang Q, Sun Z, Wu ML, Chen XY, Li C, Kong QY and Liu J. Metabolic patterns and biotransformation activities of resveratrol in human glioblastoma cells: relevance with therapeutic efficacies. PLoS One. 2011; 6(11):e27484.

14. Sun Z, Li H, Shu XH, Shi H, Chen XY, Kong QY, Wu ML and Liu J. Distinct sulfonation activities in resveratrolsensitive and resveratrol-insensitive human glioblastoma cells. FEBS J. 2012; 279(13):2381-2392.

15. Chung TK, Cheung TH, Lo WK, Yim SF, Yu MY, Krajewski S, Reed JC and Wong YF. Expression of apoptotic regulators and their significance in cervical cancer. Cancer Lett. 2002; 180(1):63-68.

16. Zhang P, Li H, Wu ML, Chen XY, Kong QY, Wang XW, Sun Y, Wen S and Liu J. c-Myc downregulation: a critical molecular event in resveratrol-induced cell cycle arrest and apoptosis of human medulloblastoma cells. J Neuro-oncol. 2006; 80(2):123-131.

17. Wang Q, Li H, Liu N, Chen XY, Wu ML, Zhang KL, Kong QY and Liu J. Correlative analyses of notch signaling with resveratrol-induced differentiation and apoptosis of human medulloblastoma cells. Neurosci Lett. 2008; 438(2):168173.

18. Wen S, Li H, Wu ML, Fan SH, Wang Q, Shu XH, Kong $\mathrm{QY}$, Chen XY and Liu J. Inhibition of NF-kB signaling commits resveratrol-treated medulloblastoma cells to 
apoptosis without neuronal differentiation. J Neuro-oncol. 2011; 104(1):169-177.

19. Plascak J, Llanos A, Pennell M, Weier R and Paskett E. Neighborhood and geographic factors associated with diagnostic resolution after an abnormal breast or cervical cancer screening test among women enrolled in a patient navigator program. Cancer Epidemiol Biomarkers Prev. 2014; 23(3):569.

20. Beller U, Quinn MA, Benedet JL, Creasman WT, Ngan HY, Maisonneuve P, Pecorelli S, Odicino F and Heintz AP. Carcinoma of the vulva. FIGO 26th annual report on the results of treatment in gynecological cancer. Int J Gynaecol Obstet. 2006; 95 Suppl 1:S7-27.

21. Kim DY, Shim SH, Kim SO, Lee SW, Park JY, Suh DS, Kim JH, Kim YM, Kim YT and Nam JH. Preoperative nomogram for the identification of lymph node metastasis in early cervical cancer. Br J Cancer. 2014; 110(1):34-41.

22. Kim HS, Kim T, Lee ES, Kim HJ, Chung HH, Kim JW, Song YS and Park NH. Impact of chemoradiation on prognosis in stage IVB cervical cancer with distant lymphatic metastasis. Cancer Res Treat. 2013; 45(3):193201.

23. Schefter T, Winter K, Kwon JS, Stuhr K, Balaraj K, Yaremko BP, Small W Jr, Sause W and Gaffney D. RTOG 0417: efficacy of bevacizumab in combination with definitive radiation therapy and cisplatin chemotherapy in untreated patients with locally advanced cervical carcinoma. Int J Radiat Oncol Biol Phys. 2014; 88(1):101-105.

24. Disilvestro PA, Ali S, Craighead PS, Lucci JA, Lee YC, Cohn DE, Spirtos NM, Tewari KS, Muller C, Gajewski WH, Steinhoff MM and Monk BJ. Phase III randomized trial of weekly cisplatin and irradiation versus cisplatin and tirapazamine and irradiation in stages IB2, IIA, IIB, IIIB, and IVA cervical carcinoma limited to the pelvis: a gynecologic oncology group study. J Clin Oncol. 2014; 32(5):458-464.

25. Schlumbrecht MP, Sun CC, Huang MS, Zandstra F and Bodurka DC. Lifestyle modification in cervical cancer survivors: an ongoing need. Int J Gynecol Cancer. 2014; 24(3):570-575.

26. Fruscio R, Villa A, Chiari S, Vergani P, Ceppi L, Dell'Orto F, Dell'Anna T, Chiappa V, Bonazzi CM, Milani R, Mangioni C and Locatelli A. Delivery delay with neoadjuvant chemotherapy for cervical cancer patients during pregnancy: a series of nine cases and literature review. Gynecol Oncol. 2012; 126(2):192-197.

27. Jang M, Cai L, Udeani GO, Slowing KV, Thomas CF, Beecher CW, Fong HH, Farnsworth NR, Kinghorn AD, Mehta RG, Moon RC and Pezzuto JM. Cancer chemopreventive activity of resveratrol, a natural product derived from grapes. Science. 1997; 275(5297):218-220.

28. Zoberi I, Bradbury CM, Curry HA, Bisht KS, Goswami PC, Roti Roti JL and Gius D. Radiosensitizing and antiproliferative effects of resveratrol in two human cervical tumor cell lines. Cancer Lett. 2002; 175(2):165-173.
29. García-Zepeda SP, García-Villa E, Díaz-Chávez J, Hernández-Pando R and Gariglio P. Resveratrol induces cell death in cervical cancer cells through apoptosis and autophagy. Eur J Cancer Prev. 2013; 22(6):577-584.

30. Mémin E, Hoque M, Jain MR, Heller DS, Li H, Cracchiolo B, Hanauske-Abel HM, Pe'ery T and Mathews MB. Blocking eIF5A modification in cervical cancer cells alters the expression of cancer-related genes and suppresses cell proliferation. Cancer Res. 2014; 74(2):552-562.

31. Feng D, Wu J, Tian Y, Zhou H, Zhou Y, Hu W, Zhao W, Wei H, Ling B and Ma C. Targeting of histone deacetylases to reactivate tumour suppressor genes and its therapeutic potential in a human cervical cancer xenograft model. PLoS One. 2013; 8(11):e80657.

32. Gu W, Yeo E, McMillan N and Yu C. Silencing oncogene expression in cervical cancer stem-like cells inhibits their cell growth and self-renewal ability. Cancer Gene Ther. 2011; 18(12):897-905.

33. Iida K, Nakayama K, Rahman MT, Rahman M, Ishikawa M, Katagiri A, Yeasmin S, Otsuki Y, Kobayashi H, Nakayama $\mathrm{S}$ and Miyazaki K. EGFR gene amplification is related to adverse clinical outcomes in cervical squamous cell carcinoma, making the EGFR pathway a novel therapeutic target. Br J Cancer. 2011; 105(3):420-427.

34. Bajaj J, Maliekal TT, Vivien E, Pattabiraman C, Srivastava S, Krishnamurthy H, Giri V, Subramanyam D and Krishna S. Notch signaling in CD66+ cells drives the progression of human cervical cancers. Cancer Res. 2011; 71(14):48884897.

35. Ramachandran I, Thavathiru E, Ramalingam S, Natarajan G, Mills WK, Benbrook DM, Zuna R, Lightfoot S, Reis A, Anant and Queimado L. Wnt inhibitory factor 1 induces apoptosis and inhibits cervical cancer growth, invasion and angiogenesis in vivo. Oncogene. 2012; 31(22):2725-2737.

36. Shukla S, Shishodia G, Mahata S, Hedau S, Pandey A, Bhambhani S, Batra S, Basir SF, Das BC and Bharti AC. Aberrant expression and constitutive activation of STAT3 in cervical carcinogenesis: implications in high-risk human papillomavirus infection. Mol Cancer. 2010; 9:282.

37. Hope C, Planutis K, Planutiene M, Moyer MP, Johal KS, Woo J, Santoso C, Hanson JA and Holcombe RF. Low concentrations of resveratrol inhibit Wnt signal throughput in colon-derived cells: implications for colon cancer prevention. Mol Nutr Food Res. 2008; 52 Suppl 1:S52-61.

38. Liu L, Fan Z, Tang Y and Ke Z. The resveratrol attenuates ethanol-induced hepatocyte apoptosis via inhibiting ERrelated caspase-12 activation and PDE activity in vitro. Alcohol Clin Exp Res. 2014; 38(3):683-693.

39. Zhang M, Zhou $X$ and Zhou K. Resveratrol inhibits human nasopharyngeal carcinoma cell growth via blocking pAkt/p70S6K signaling pathways. Int J Mol Med. 2013; 31(3):621-627.

40. Yan S, Li Z and Thiele CJ. Inhibition of STAT3 with orally active JAK inhibitor, AZD1480, decreases tumor growth in 
neuroblastoma and pediatric sarcomas in vitro and in vivo. Oncotarget. 2013; 4(3):433-445.

41. Nelson EA, Sharma SV, Settleman J and Frank DA. A chemical biology approach to developing STAT inhibitors: molecular strategies for accelerating clinical translation. Oncotarget. 2011; 2(6):518-524.

42. Dailey DD, Anfinsen KP, Pfaff LE, Ehrhart E, Charles JB, Bønsdorff TB, Thamm DH, Powers BE, Jonasdottir TJ and Duval DL. HES1, a target of Notch signaling, is elevated in canine osteosarcoma, but reduced in the most aggressive tumors. BMC Vet Res. 2013; 9(1):130.

43. Maliekal TT, Bajaj J, Giri V, Subramanyam D and Krishna S. The role of Notch signaling in human cervical cancer: implications for solid tumors. Oncogene. 2008; 27(38):5110-5114.

44. Kwan HT, Chan DW, Cai PC, Mak CS, Yung MM, Leung TH, Wong OG, Cheung AN and Ngan HY. AMPK activators suppress cervical cancer cell growth through inhibition of DVL3 mediated Wnt/ $\beta$-catenin signaling activity. PLoS One. 2013; 8(1):e53597.

45. Schröer N, Pahne J, Walch B, Wickenhauser C and Smola S. Molecular pathobiology of human cervical high-grade lesions: paracrine STAT3 activation in tumor-instructed myeloid cells drives local MMP-9 expression. Cancer Res. 2011; 71(1):87-97.

46. Kamakura S, Oishi K, Yoshimatsu T, Nakafuku M, Masuyama N and Gotoh Y. Hes binding to STAT3 mediates crosstalk between Notch and JAK-STAT signalling. Nat Cell Biol. 2004; 6(6):547-554.

47. Sengupta A, Banerjee D, Chandra S, Banerji SK, Ghosh R, Roy R and Banerjee S. Deregulation and cross talk among Sonic hedgehog, Wnt, Hox and Notch signaling in chronic myeloid leukemia progression. Leukemia. 2007; 21(5):949955.

48. Liu J, Wang Q, Wu DC, Wang XW, Sun Y, Chen XY, Zhang KL and Li H. Differential regulation of CYP1A1 and CYP1B1 expression in resveratrol-treated human medulloblastoma cells. Neurosci Lett. 2004; 363(3):257261.

49. Araki Y, Okamura S, Hussain SP, Nagashima M, He P, Shiseki M, Miura K and Harris CC. Regulation of cyclooxygenase-2 expression by the Wnt and ras pathways. Cancer Res. 2003; 63(3):728-734.

50. Chiaramonte R, Basile A, Tassi E, Calzavara E, Cecchinato V, Rossi V, Biondi A and Comi P. A wide role for NOTCH1 signaling in acute leukemia. Cancer Lett. 2005; 219(1):113-120.

51. Walsh J and Andrews PW. Expression of Wnt and Notch pathway genes in a pluripotent human embryonal carcinoma cell line and embryonic stem cell. APMIS. 2003; 111(1):197-210.

52. Scintu F, Reali C, Pillai R, Badiali M, Sanna MA, Argiolu F, Ristaldi MS and Sogos V. Differentiation of human bone marrow stem cells into cells with a neural phenotype: diverse effects of two specific treatments. BMC Neurosci. 2006; 7:14.

53. Katoh M. Frequent up-regulation of WNT2 in primary gastric cancer and colorectal cancer. Int J Oncol. 2001; 19(5):1003-1007.

54. Saitoh T, Mine T and Katoh M. Frequent up-regulation of WNT5A mRNA in primary gastric cancer. Int J Mol Med. 2002; 9(5):515-519.

55. Ebert MP, Fei G, Kahmann S, Müller O, Yu J, Sung JJ and Malfertheiner P. Increased beta-catenin mRNA levels and mutational alterations of the APC and beta-catenin gene are present in intestinal-type gastric cancer. Carcinogenesis. 2002; 23(1):87-91.

56. Yang J, Liao X, Agarwal MK, Barnes L, Auron PE and Stark GR. Unphosphorylated STAT3 accumulates in response to IL- 6 and activates transcription by binding to NFкB. Genes Dev. 2007; 21(11):1396-1408.

57. Sonnenblick A, Levy C, Razin E. Interplay between MITF, PIAS3, and STAT3 in mast cells and melanocytes. Mol Cell Biol. 2004; 24(24):10584-10592.

58. Shearman MS, Beher D, Clarke EE, Lewis HD, Harrison T, Hunt P, Nadin A, Smith AL, Stevenson G and Castro JL. L-685,458, an aspartyl protease transition state mimic, is a potent inhibitor of amyloid beta-protein precursor gammasecretase activity. Biochemistry. 2000; 39(30):8698-8704.

59. Branam AM, Davis NM, Moore RW, Schneider AJ, Vezina CM and Peterson RE. TCDD inhibition of canonical wnt signaling disrupts prostatic bud formation in mouse urogenital sinus. Toxicol Sci. 2013; 133(1):42-53.

60. Rahaman SO, Harbor PC, Chernova O, Barnett GH, Vogelbaum MA and Haque SJ. Inhibition of constitutively active P-STAT3 suppresses proliferation and induces apoptosis in glioblastoma multiforme cells. Oncogene. 2002; 21(55):8404-8413. 